\title{
Effect of long-term refeeding on protein metabolism in patients with cirrhosis of the liver
}

\author{
BY JENS KONDRUP, KLAUS NIELSEN AND ANDERS JUUL
}

The Clinical Nutrition Unit and Division of Hepatology, Department of Medicine A \& Department of Growth and Reproduction, Rigshospitalet, 9 Blegdamsvej, DK-2100 Ø. Copenhagen, Denmark

(Received 17 November 1995 - Revised 21 March 1996 - Accepted 17 April 1996)

\begin{abstract}
Patients with cirrhosis of the liver require an increased amount of protein to achieve $\mathbf{N}$ balance. However, the utilization of protein with increased protein intake, i.e. the slope from regression analysis of $\mathbf{N}$ balance $v$. intake, is highly efficient (Nielsen et al. 1995). In the present study, protein requirement and protein utilization were investigated further by measuring protein synthesis and degradation. In two separate studies, five or six patients with cirrhosis of the liver were refed on a balanced diet for an average of 2 or 4 weeks. Protein and energy intakes were doubled in both studies. Initial and final whole-body protein metabolism was measured in the fed state by primed continous $\left[{ }^{15} \mathrm{~N}\right]$ lglycine infusion. Refeeding caused a statistically significant increase of about $30 \%$ in protein synthesis in both studies while protein degradation was only slightly affected. The increase in protein synthesis was associated with significant increases in plasma concentrations of total amino acids $(25 \%)$, leucine $(58 \%)$, isoleucine $(82 \%)$, valine $(72 \%)$, proline $(48 \%)$ and triiodothyronine (27\%) while insulin, growth hormone, insulin-like growth factor (IGF)-I and IGF-binding protein-3 were not changed significantly. The results indicate that the efficient protein utilization is due to increased protein synthesis, rather than decreased protein degradation, and suggest that increases in plasma amino acids may be responsible for the increased protein synthesis. A comparison of the patients who had a normal protein requirement with the patients who had an increased protein requirement suggests that the increased protein requirement is due to a primary increase in protein degradation. It is speculated that this is due to low levels of IGF-I secondary to impaired liver function, since initial plasma concentration of IGF-I was about $25 \%$ of control values and remained low during refeeding.
\end{abstract}

Nitrogen retention: Protein metabolism: Alcoholic cirrhosis

A large number of patients with liver cirrhosis are malnourished (Lautz et al. 1992) and a review of controlled studies suggested that nutritional therapy improves liver function and may improve the clinical course including mortality (Kondrup et al. 1992). However, the use of artificial nutrition was necessary in all these studies since it is often difficult to increase oral intake sufficiently in patients with cirrhosis. Even in a clinically-stable situation, protein intake is often inadequate among patients with liver cirrhosis, especially since the requirement for protein to achieve $\mathrm{N}$ balance is increased (Swart et al. 1989; Nielsen et al. 1993, 1995). In contrast, the utilization of protein with increased protein intake (i.e. the slope of balance $v$. intake) is highly efficient and considered to be similar to that of underweight individuals without organ disease (Nielsen et al. 1995).

In order to investigate regulation of protein metabolism during repletion, we performed this study in the fed state before and after refeeding. This was considered necessary because regulatory mechanisms involved in repletion after weight loss probably 
differ from the regulatory mechanisms involved in the diurnal fasting fed state transition. Repletion is thought to be characterized by sustained increases in plasma concentrations of substrates and hormones (e.g. amino acids, insulin, triiodothyronine $\left(\mathrm{T}_{3}\right)$, insulin-like growth factor (IGF)-I) that lead to net anabolism within the diurnal cycling of nutrient storage and loss (Millward, 1990).

The effect of refeeding on protein metabolism may be time dependent and, therefore, the patients were refed for an average of 2 or 4 weeks in two separate studies. Protein and energy intakes were doubled in both studies. Initial and final whole-body protein metabolism was measured by the primed continuous $\left[{ }^{15} \mathrm{~N}\right]$ glycine dual-endproducts method (Picou \& Taylor-Roberts, 1969; Jeevanandam et al. 1986). During measurement of protein metabolism the patients were given hourly sip feedings with amounts of protein and energy that were identical to the initial and final dietary intakes. Plasma hormones and substrates believed to regulate protein synthesis and degradation were also measured during sip feeding. In addition, in order to examine the response to a standardized single test meal, plasma substrates and hormones were measured at the beginning and at the end of the 4-week study. In the present study the content of energy and protein in the meal was kept constant.

Finally, in order to elucidate the mechanism of the increased protein requirement, a comparison of protein metabolism was made between the patients who had an increased requirement and the patients who had a requirement within the recommendation for healthy subjects.

\section{METHODS}

The methods employed in the refeeding protocol were essentially as described previously (Nielsen et al. 1995) and will be described in brief only.

\section{Patients}

Malnourished patients were recruited for the study when they were clinically stable, at least 1 week after admission. They all had biopsy-confirmed alcoholic cirrhosis, except one patient who had biopsy-confirmed cryptogenic cirrhosis. Patients with hepatic encephalopathy, positive results for hepatitis $\mathrm{B}_{\mathrm{s}} \mathrm{Ag}$, overt diarrhoea, renal disease, fever, or malignant diseases were not included. One patient with insulin-dependent diabetes mellitus was included in the 2-week protocol. The patients were considered malnourished if one or both of the following criteria were met: body weight (BW) $<80 \%$ of reference weight, or lean body mass (LBM) $<80 \%$ of reference value. LBM was calculated from three $24 \mathrm{~h}$ urinary creatinine excretions (Nielsen et al. 1995). The clinical status of the patients was classified according to the Child-Pugh scores A, B or C, employing measures of plasma bilirubin, plasma albumin, prothrombin time and the presence or absence of ascites and hepatic encephalopathy (Pugh et al. 1973). Patients were included in the study when the ability to co-operate had been verified during an initial $3 \mathrm{~d}$ screening procedure (Nielsen et al. 1995). The patients stayed in the department throughout the study under metabolic ward conditions. To the best of our knowledge the patients abstained from alcohol during the study period but this was not controlled by measurement of alcohol in blood or urine. A large number of the patients were studied while being evaluated for liver transplantation, and any suspicion of continued alcohol intake would have precluded transplantation. 


\section{Refeeding protocol}

The patients in the 4-week protocol were the last eight of the fifteen patients described earlier (Nielsen et al. 1995). After a $3 \mathrm{~d}$ baseline period in which protein and energy intake was kept at the pre-study level of the $3 \mathrm{~d}$ screening period, protein and energy intake was increased by $15-20 \%$ in subsequent periods of $4-6 \mathrm{~d}$. The energy composition of diets with respect to protein, carbohydrate and fat was kept fixed at the composition recorded during the pre-study period. The diets were customary mixed daily diets, prepared in the kitchen associated with the department. Two of the eight patients did not continue to increase dietary intake and the data from these patients are only included in the extended analysis of initial results (Table 7).

Patients included in the 2-week protocol were treated similarly, except that intake of energy and protein was increased by approximately $20 \%$ after each $3 \mathrm{~d}$ period, in order to reach a doubling of dietary intake after 2 weeks. This seemed feasible since no patients developed encephalopathy during the preceding more cautious 4-week protocol.

\section{Standardized test meal}

At the beginning and at the end of the 4-week protocol, four of the eight patients were given a standard liquid meal containing (per kg body weight) $50 \mathrm{~kJ}$ and $0.4 \mathrm{~g}$ protein, after an overnight fast. Blood samples were taken for analysis of substrates and hormones before the meal and 1 and $3 \mathrm{~h}$ after the meal.

\section{Analytical methods}

Nitrogen balance and energy intake. In the 4-week protocol initial and final $\mathrm{N}$ balance was calculated from weighed dietary intake, with the $\mathrm{N}$ content given in food tables, and from urinary $\mathrm{N}$ excretion to which was added an amount equal to $17 \%$ of mean dietary $\mathrm{N}$ intake $(2.5 \mathrm{~g} \mathrm{~N})$ to correct for skin and faecal loss (Bingham \& Cummings, 1985). N excretion was measured in $24 \mathrm{~h}$ urine collections during the whole study by a microKjeldahl technique (Keltec Systems; Tecator AB, Hoganaes, Sweden). Protein balance was then calculated as:

$$
\text { protein balance }=\text { protein intake }-(6.25 \times(24 \text { h urinary } \mathrm{N}+2.5)) \text {. }
$$

This procedure gave reliable results according to a validation study in the same patients (Nielsen et al. 1995). In the 2-week protocol, $\mathrm{N}$ content of food (duplicate-portion technique) and faecal $\mathrm{N}$ content were measured in an initial and final $3 \mathrm{~d}$ period just before the $\left[{ }^{15} \mathrm{~N}\right]$ glycine study (Nielsen et al. 1995). Skin N loss was taken to be $4 \%$ of protein intake (Bingham \& Cummings, 1985). Protein balance was then calculated as:

$$
\begin{aligned}
\text { protein balance }= & \text { protein intake }-(6.25 \times(24 \mathrm{~h} \text { urinary } \mathrm{N}+\text { faecal } \mathrm{N}) \\
& +0.04 \times \text { protein intake }) .
\end{aligned}
$$

A correction for loss of urine was performed in the 4-week protocol by giving 4 aminobenzoic acid tablets (Bingham \& Cummings, 1983). The correction turned out to be of minor quantitative importance in these patients, selected because of ability to cooperate (Nielsen et al. 1995), and it was omitted from the 2-week protocol.

As described by Nielsen et al. (1995), the protein requirement for $\mathrm{N}$ balance, and protein utilization, were calculated for each patient by linear regression analysis of $\mathrm{N}$ balance $v$. protein intake for each period of protein intake, i.e. at least six balance periods 
for each patient. The requirement for protein equals the intercept at balance $=0$ and utilization is the the slope of the regression line.

Energy intake was calculated from weighed dietary intake by means of food tables. A validation study showed that measurement in duplicate portions of food on average gave $13 \%$ lower energy content (Nielsen et al. 1995) but this was ignored in the present study where exact energy balance was not of crucial importance.

Protein metabolism. On day 3 of the baseline period a primed continuous intravenous infusion of $\left[{ }^{15} \mathrm{~N}\right]$ glycine ( $98 \%$, Sigma Chemical Company, St Louis, MO, USA) was initiated at 11.00 hours. A bolus of $0.52 \mathrm{mg}{ }^{15} \mathrm{~N} / \mathrm{kg} \mathrm{BW}$ was given over $10 \mathrm{~min}$ followed by a continous infusion of $0.42 \mathrm{mg}{ }^{15} \mathrm{~N} / \mathrm{kg} \mathrm{BW}$ per $\mathrm{h}$ for $29 \mathrm{~h}$ (Jeevanandam et al. 1986). From the next morning the same amount of energy and protein was given in equallydivided doses at hourly intervals from 07.00 to 20.00 hours, in the form of a mixture of casein-based (Nutridrink; Nutricia, Zoetermeer, The Netherlands) and soyabean-proteinbased (Top-Up; Ferrosan, Copenhagen, Denmark) liquid supplements (casein-soyabean protein; $2: 1, \mathrm{w} / \mathrm{w}$ ). Urine samples for analysis of isotope enrichment were taken at $2 \mathrm{~h}$ intervals from 12.00 to 16.00 hours, i.e. after $25-29 \mathrm{~h}$ isotope infusion when isotopic steady-state was established. The amount of $\left[{ }^{15} \mathrm{~N}\right]$ glycine administered during the continuous infusion was about $6 \%$ of the amount of glycine given in dietary protein. The tracer study was performed twice in each subject and the final $\left[{ }^{15} \mathrm{~N}\right]$ glycine investigation also took place after $3 \mathrm{~d}$ of fixed, increased, dietary intake.

A pre-infusion urine sample was used to determine the ${ }^{15} \mathrm{~N}$ background. $\mathrm{NH}_{3}$ in urine and $\mathrm{NH}_{3}$ derived from urinary urea was isolated as described previously (Nielsen et al. 1994). The samples were analysed by using a RoboPrep ${ }^{\circledR}$ elemental analyser connected with a TracerMass ${ }^{\circledR}$ isotope-ratio mass spectrometer (Europa Scientific, Crewe, Ches.). $\mathrm{NH}_{3}$ and urea fluxes were calculated separately from the atom percentage enrichment (APE) at plateau ${ }^{15} \mathrm{~N}$ enrichment (Picou \& Taylor-Roberts, 1969). Average flux was calculated as the geometric average of $\mathrm{NH}_{3}$ and urea fluxes since this calculation does not favour any of the two extreme models discussed by Fern et al. (1985). Protein synthesis and degradation was calculated according to the equation:

$$
\mathrm{Q}_{\mathrm{geo}}=\mathrm{I}+\mathrm{D}=\mathrm{E}+\mathrm{S} \text {, }
$$

in which $Q_{g e o}$ is flux, $I$ is intake, $D$ is degradation, $E$ is excretion of urinary $N$ recalculated to protein by multiplication by 6.25 , and $S$ is synthesis. Blood samples were taken at 14.00 hours, i.e. when the second of the three urine samples was collected.

\section{Substrates and hormones}

Routine laboratory tests were analysed by standard methods. As a quantitative test of liver function, galactose elimination capacity was determined according to Tygstrup (1966). Plasma insulin and glucagon were determined as described previously (Nielsen et al. 1995). IGF-I in serum was determined after acid-ethanol extraction and cryoprecipitation as described by Bang et al. (1991) and Juul et al. (1995), and IGF-binding protein (GFBP)3 was determined according to Blum et al. (1990). Due to large inter-assay variations each hormone was measured in all samples from one protocol on the same day. Plasma amino acid composition was measured by the Pico-Tag ${ }^{\circledR}$ method, Waters Chromatography Division, Milford, MA., USA. In Table 5 the concentration of total amino acids in plasma was calculated by summation of individual amino acids. In Tables 6 and 7, total amino acids in plasma was measured by the dinitrofluorobenzene method (Goodwin, 1970). 


\section{Statistics}

Results are expressed as means with their standard errors. Statistical significance was evaluated by Student's $t$ test for paired or unpaired observations, as appropriate.

\section{Ethics}

The study was approved by the local Ethics Committee and conducted in accordance with the principles for human experimentation as defined in the Declaration of Helsinki II.

\section{RESULTS}

The initial clinical and nutritional indices for the eleven patients who completed the two protocols are shown combined in Table 1. Eight of the ten patients with alcoholic liver cirrhosis admitted to alcohol abuse. Their mean intake had been 93 (SE 12; range 60-180) $\mathrm{g} / \mathrm{d}$ for a mean of 12 (SE 2; range 5-20) years. Refeeding was begun at a mean of 18 (SE 3; range 7-44) $d$ after admission. The patients were refed for a mean of 31 (SE 3 ; range 20-

Table 1. Clinical and nutritional status of eleven patients with liver cirrhosis before refeeding (Mean values with their standard errors)

\begin{tabular}{|c|c|c|c|}
\hline & $n$ & Mean & SE \\
\hline Male & 8 & & \\
\hline Female & 3 & & \\
\hline Child-Pugh group*: A & 1 & & \\
\hline B & 6 & & \\
\hline$\overline{\mathrm{C}}$ & 4 & & \\
\hline Age (years) & & 45 & 2 \\
\hline Height (m) & & 174 & 2 \\
\hline $\mathrm{Wt}+: \mathbf{k g}$ & & 57 & 3 \\
\hline$\%$ of reference & & 83 & 3 \\
\hline Lean body mass: $72 \mathrm{~h}$ creatinine $(\mathrm{kg})$ & & 29 & 1 \\
\hline$\%$ reference & & 57 & 8 \\
\hline Triceps skinfold: $\mathrm{cm}$ & & 0.68 & 0.07 \\
\hline$\%$ reference & & 51 & 6 \\
\hline Mid-arm-muscle-area: $\mathrm{cm}^{2}$ & & 38 & 3 \\
\hline$\%$ reference & & 65 & 3 \\
\hline Albumin $(\mu \mathrm{mol} / 1) \ddagger$ & & 462 & 18 \\
\hline Prothrombin index $\ddagger$ & & 0.55 & 0.05 \\
\hline Alanine aminotransferase $(E C$ 2.6.1.2; $1 \mathrm{U} / 1) \ddagger$ & & 34 & 7 \\
\hline Alkaline phosphatase $(E C$ 3.1.3.1; $\Pi U / 1) \ddagger$ & & 294 & 46 \\
\hline Bilirubin $(\mu \mathrm{mol} / \mathrm{l}) \ddagger$ & & 71 & 38 \\
\hline Galactose elimination capacity: $\mathrm{mmol} / \mathrm{min}$ & & 1.17 & 0.09 \\
\hline$\%$ reference & & 48 & 4 \\
\hline $\operatorname{IgG}(\mu \mathrm{mol} / \mathrm{l}) \ddagger$ & & 134 & 14 \\
\hline $\mathrm{IgA}(\mu \mathrm{mol} / \mathrm{l}) \ddagger$ & & 59 & 8 \\
\hline IgM $(\mu \mathrm{mol} / 1) \ddagger$ & & 3.6 & 1 \\
\hline
\end{tabular}

Ig, immunoglobulin.

* Child-Pugh group classification is a clinical score for severity of liver disease (Pugh et al. 1973).

†All patients had ascites.

$\ddagger$ Reference values given by the Department of Clinical Chemistry: albumin 550-830 $\mu \mathrm{mol} / 1$, prothrombin index $0.70-$ 1.30 , alanine aminotransferase $10-40 \mathrm{IU} / 1$, alkaline phosphatase $80-275 \mathrm{IU} / 1$, bilinubin $4-17 \mu \mathrm{mol} / 1$, IgG $36-89$ $\mu \mathrm{mol} / 1$, IgA 3.8-21.0 $\mu \mathrm{mol} / 1$, IgM 0.3-3.7 $\mu \mathrm{mol} / 1$. 
Table 2. Protein intake and nitrogen balance of eleven patients with liver cirrhosis during refeeding ( $g$ protein $/ \mathrm{kg}$ per $\mathrm{d})^{*}$

(Mean values with their standard errors)

\begin{tabular}{|c|c|c|c|c|}
\hline & \multicolumn{2}{|c|}{$\begin{array}{l}\text { 2-week protocol } \\
\text { (n 5) }\end{array}$} & \multicolumn{2}{|c|}{$\begin{array}{c}\text { 4-week protocol } \\
(n 6)\end{array}$} \\
\hline & Mean & $\mathrm{SE}$ & Mean & SE \\
\hline Protein intake: Initial & 1.04 & 0.16 & 0.95 & 0.07 \\
\hline Final & $2 \cdot 12$ & 0.38 & 1.78 & 0.16 \\
\hline $\mathrm{N}$ balance: Initial & $-0.08^{\mathrm{a}}$ & 0.24 & $-0.02^{\mathrm{c}}$ & 0.08 \\
\hline Final & $0.90^{\mathrm{b}}$ & 0.36 & $0.51^{\mathrm{d}}$ & 0.11 \\
\hline Utilization $\dagger(\mathrm{g} / \mathrm{g})$ & 0.95 & 0.17 & 1.08 & 0.15 \\
\hline
\end{tabular}

a,b,c,d Mean values with different superscript letters within the same column were significantly different: ${ }^{\mathrm{a}, \mathrm{b}} P=0.027$; c,d $P=0.001$.

*For details of patients and procedures, see Table 1 and pp. 198-200.

$\uparrow$ Calculated by linear regression analysis of $\mathrm{N}$ balance $v$. protein intake.

41) $d$ in the 4-week protocol and 14.2 (SE 0.52; range 13-16) $d$ in the 2-week protocol. All patients had ascites and BW increased by a mean of $4 \%$ during refeeding (data not shown).

Table 2 shows that, in both protocols, protein intake doubled and $\mathrm{N}$ balance improved. As calculated by linear regression analysis of $\mathrm{N}$ balance $v$. protein intake, protein utilization was close to 1 in both protocols. Estimated protein requirement was 0.98 (SE $0.13) \mathrm{g} / \mathrm{kg}$ per $\mathrm{d}$ in the 2-week protocol and 0.81 (SE 0.10) $\mathrm{g} / \mathrm{kg}$ per $\mathrm{d}$ in the 4-week protocol. The $r^{2}$ of regression analysis was 0.86 (SE 0.05 ) in the 2-week protocol and 0.87 (SE 0.04) in the 4 week protocol. The patients were initially in energy balance (intake 7.9 (SE 0.7) $\mathrm{MJ} / \mathrm{d} v$. energy expenditure $7.5(\mathrm{SE} 0.3) \mathrm{MJ} / \mathrm{d}$ ), as calculated by the factorial method described previously (Nielsen et al. 1995). During refeeding, energy intake was increased in proportion to protein intake.

Table 3 shows the background ${ }^{15} \mathrm{~N}$ atom percentage, and the APE as averages of three samples taken 25,27 and $29 \mathrm{~h}$ after initiating isotope infusion. The analytical precision (CV) was $0.8 \%$ when applying 10 samples of $100 \mu \mathrm{g} \mathrm{N}$ sample (consisting of glycine enriched by 0.05 APE by mixing with $\left[{ }^{15} \mathrm{~N}\right]$ glycine) to the mass spectrometer. To evaluate whether an isotope steady-state was actually achieved, the CV for APE of $\mathrm{NH}_{3}$ and urea was calculated for each set of three measurements (i.e the three $2 \mathrm{~h}$ sampling periods). The average $\mathrm{CV}$ for the total of twenty-two sets of urinary $\mathrm{NH}_{3}$ was 5.2 (SE 0.7 ) \%, and for urea 3.4 (SE 0.4)\%. At the second investigation the background atom percentage of $\mathrm{NH}_{3}$ and urea was negligibly higher than the first background measurements.

Table 4 shows that increased dietary intake stimulated flux and protein synthesis to the same extent in both protocols. Protein degradation decreased after 2 weeks refeeding but was unchanged after 4 weeks. Protein balance in Table 4 (degradation subtracted from synthesis) is higher than that of Table 2 since it is customary in the calculation of protein synthesis to subtract only urinary $\mathrm{N}$ from protein flux, rather than the sum of $\mathrm{N}$ excretion in urine, faeces and skin. $\mathrm{N}$ in faeces and skin may to an unknown extent be proteins synthesized in the body. For comparison, results are shown from a study in healthy individuals by Pacy et al. (1994).

Two of the eight patients originally included in the 4-week protocol had returned to their initial protein intake and $\mathrm{N}$ balance at the end of the study (after 28 and $31 \mathrm{~d}$ respectively), after an intermediate period of increased intake. Despite this, these two patients were also subjected to the second $\left[{ }^{15} \mathrm{~N}\right]$ glycine investigation. On average, flux, synthesis and degradation had decreased by $20-25 \%$ at the second investigation. 
Table 3. Individual values of background isotope enrichment and atom percentage excess (APE) during steady-state isotope infusion in eleven patients with liver cirrhosis*

\begin{tabular}{|c|c|c|c|c|c|}
\hline \multirow[t]{2}{*}{ Patient } & & \multicolumn{2}{|c|}{ First study } & \multicolumn{2}{|c|}{ Second study } \\
\hline & & Background & APE & Background & APE \\
\hline \multicolumn{6}{|c|}{ 4-week protocol } \\
\hline \multirow[t]{2}{*}{$\mathrm{JH}$} & $\mathrm{NH}_{3}$ & 0.366 & 0.076 & 0.371 & 0.086 \\
\hline & Urea & 0.367 & 0.065 & 0.374 & 0.045 \\
\hline \multirow[t]{2}{*}{ LQ } & $\mathrm{NH}_{3}$ & 0.371 & 0.070 & 0.369 & 0.083 \\
\hline & Urea & 0.371 & 0.071 & 0.370 & 0.089 \\
\hline \multirow[t]{2}{*}{ PM } & $\mathrm{NH}_{3}$ & 0.371 & 0.115 & 0.371 & 0.084 \\
\hline & Urea & 0.370 & 0.084 & 0.371 & 0088 \\
\hline \multirow[t]{2}{*}{$\mathrm{JL}$} & $\mathrm{NH}_{3}$ & 0.368 & 0.120 & 0.376 & 0.112 \\
\hline & Urea & $0 \cdot 371$ & 0.080 & 0.374 & 0.072 \\
\hline \multirow[t]{2}{*}{ BTO } & $\mathrm{NH}_{3}$ & 0.372 & 0.115 & 0.372 & 0.070 \\
\hline & Urea & 0.368 & 0.100 & 0.371 & 0.061 \\
\hline \multirow[t]{2}{*}{ LO } & $\mathrm{NH}_{3}$ & 0.368 & 0.115 & 0.379 & 0.065 \\
\hline & Urea & 0.368 & 0.071 & 0.375 & 0.052 \\
\hline \multicolumn{6}{|c|}{ 2-week protocol } \\
\hline \multirow[t]{2}{*}{$\mathrm{OM}$} & $\mathrm{NH}_{3}$ & 0.366 & 0.129 & 0.373 & 0.086 \\
\hline & Urea & 0.368 & 0.095 & 0.371 & 0.072 \\
\hline \multirow[t]{2}{*}{ IGN } & $\mathrm{NH}_{3}$ & $0-367$ & 0.052 & 0.373 & 0.040 \\
\hline & Urea & 0.367 & 0.034 & 0.368 & 0.045 \\
\hline \multirow[t]{2}{*}{ TW } & $\mathrm{NH}_{3}$ & 0.370 & 0.075 & 0.371 & 0.070 \\
\hline & Urea & 0.370 & 0.065 & 0.372 & 0.058 \\
\hline \multirow[t]{2}{*}{ CFP } & $\mathrm{NH}_{3}$ & 0.369 & 0.088 & 0.374 & 0.049 \\
\hline & Urea & 0.367 & 0.055 & 0.370 & 0.042 \\
\hline \multirow[t]{2}{*}{$\mathrm{CN}$} & $\mathrm{NH}_{3}$ & 0.368 & 0.130 & 0.383 & 0.086 \\
\hline & Urea & 0.367 & 0.059 & 0.376 & 0.066 \\
\hline
\end{tabular}

*For details of patients and procedures, see Table 1 and pp. 198-200.

Table 4. Protein metabolism in eleven patients with liver cirrhosis during hourly feeding before and after refeeding $(\mathrm{g} / \mathrm{kg}$ per $\mathrm{d})$ *

(Mean values with their standard errors for no. of patients shown)

\begin{tabular}{|c|c|c|c|c|c|c|c|c|}
\hline & \multirow[b]{2}{*}{$n$} & \multicolumn{2}{|c|}{ Before } & \multicolumn{2}{|c|}{2 weeks refeeding } & \multicolumn{2}{|c|}{4 weeks refeeding } & \multirow{2}{*}{$\begin{array}{c}\text { Statistical significance } \\
\text { of the differencet: } \\
P\end{array}$} \\
\hline & & Mean & SE & Mean & SE & Mean & SE & \\
\hline Flux & 5 & 3.95 & 0.55 & 4.80 & 0.53 & - & - & 0.016 \\
\hline Synthesis & 5 & $3 \cdot 14$ & 0.48 & 3.88 & 0.44 & - & - & 0.044 \\
\hline Degradation & 5 & 2.91 & 0.51 & 2.69 & 0.51 & - & - & 0.040 \\
\hline Flux & 6 & 2.86 & 0.22 & - & - & 3.83 & 0.28 & 0.022 \\
\hline Synthesis & 6 & 2.15 & 0.24 & - & - & 2.81 & 0.35 & 0.033 \\
\hline Degradation & 6 & 1.92 & 0.28 & - & - & 2.06 & 0.37 & \\
\hline \multicolumn{9}{|l|}{ Protein intaket } \\
\hline$(\mathrm{g} / \mathrm{kg}$ per $\mathrm{d}) \ldots$ & & 0.75 & & 1.5 & & & & \\
\hline Fluxt & & 4.37 & & 4.70 & & & & \\
\hline Synthesis $\dagger$ & & $4 \cdot 22$ & & 5.00 & & & & \\
\hline Degradation $\dagger$ & & 3.62 & & $3 \cdot 20$ & & & & \\
\hline
\end{tabular}

*For details of patients and procedures; see Table 1 and pp. 198-200.

†Data recalculated from Pacy et al. (1994). After 2 weeks of the protein intakes specified, healthy subjects were investigated by $\left[{ }^{13} \mathrm{C}\right]$ leucine infusion during hourly feeding for $12 \mathrm{~h}$ (for further details, see p. 207).

†Mean values were significantly different from those before refeeding by paired $t$ test. 
Table 5 shows changes in plasma substrates and hormones in the 2-week protocol, as measured at 14.00 hours during hourly feeding and $\left[{ }^{15} \mathrm{~N}\right]$ glycine infusion. Lysine, tyrosine, branched-chain amino acids (BCAA), proline, glucagon and $T_{3}$ showed significant increases.

In the 4-week protocol only total plasma amino acids, IGF-I and IGFBP-3 were measured at 14.00 hours during the $\left[{ }^{15} \mathrm{~N}\right]$ glycine infusion. Also in this protocol, total plasma amino acids increased (by $55 \% ; P=0.008$ ) and neither IGF-I nor IGFBP-3 increased significantly.

Table 5. Plasma substrate and hormone levels of five patients with liver cirrhosis during hourly feeding before and after 2 weeks of refeeding* $\dagger$

(Mean values with their standard errors)

\begin{tabular}{|c|c|c|c|c|c|}
\hline & \multicolumn{2}{|c|}{ Initial value } & \multicolumn{2}{|c|}{ Final value } & \multirow{2}{*}{$\begin{array}{c}\text { Statistical significance } \\
\text { of difference } \\
\text { (paired } t \text { test): } P\end{array}$} \\
\hline & Mean & SE & Mean & $\mathrm{SE}$ & \\
\hline Glucose (mmol/l) & $10 \cdot 00$ & $3 \cdot 27$ & $13 \cdot 51$ & 5.77 & \\
\hline Lactate $(\mathrm{mmol} / \mathrm{l})$ & 1.71 & 0.21 & 1.83 & 0.19 & \\
\hline Free fatty acids (mmol/l) & 0.32 & 0.09 & 0.28 & 0.08 & \\
\hline$\beta$-hydroxybutyrate $(\mu \mathrm{mol} / 1)$ & 53 & 17 & 39 & 4 & \\
\hline Total amino acids (mmol/l) & 3.85 & 0.24 & 4.82 & 0.21 & 0.049 \\
\hline Lys $(\mu \mathrm{mol} / 1)$ & 180 & 11 & 262 & 26 & 0.026 \\
\hline Thr $(\mu \mathrm{mol} / \mathrm{l})$ & 144 & 27 & 186 & 21 & \\
\hline $\mathrm{His}(\mu \mathrm{mol} / \mathrm{l})$ & 95 & 11 & 95 & 16 & \\
\hline $\operatorname{Trp}(\mu \mathrm{mol} / \mathrm{l})$ & 74 & 8 & 102 & 12 & \\
\hline Phe $(\mu \mathrm{mol} / \mathrm{l})$ & 115 & 15 & 172 & 26 & \\
\hline Tyr $(\mu \mathrm{mol} / \mathrm{l})$ & 145 & 23 & 259 & 33 & 0.011 \\
\hline Met $(\mu \mathrm{mol} / \mathrm{l})$ & 78 & 31 & 72 & 16 & \\
\hline Cys $(\mu \mathrm{mol} / 1)$ & 260 & 35 & 274 & 29 & \\
\hline Leu $(\mu \mathrm{mol} / 1)$ & 85 & 3 & 133 & 11 & 0.011 \\
\hline Ile $(\mu \mathrm{mol} / \mathrm{l})$ & 46 & 6 & 79 & 7 & 0.024 \\
\hline Val $(\mu \mathrm{mol} / \mathrm{l})$ & 135 & 12 & 234 & 26 & 0.004 \\
\hline Ala $(\mu \mathrm{mol} / \mathrm{l})$ & 392 & 61 & 528 & 31 & \\
\hline $\mathrm{Glu}(\mu \mathrm{mol} / 1)$ & 55 & 7 & 89 & 17 & \\
\hline $\mathrm{Gln}(\mu \mathrm{mol} / \mathrm{l})$ & 766 & 100 & 775 & 54 & \\
\hline Asn $(\mu \mathrm{mol} / \mathrm{l})$ & 223 & 19 & 295 & 17 & \\
\hline Pro $(\mu \mathrm{mol} / \mathrm{l})$ & 248 & 19 & 355 & 8 & 0.027 \\
\hline $\operatorname{Arg}(\mu \mathrm{mol} / 1)$ & 160 & 17 & 190 & 19 & \\
\hline Orn $(\mu \mathrm{mol} / 1)$ & 94 & 9 & 120 & 16 & \\
\hline Cit $(\mu \mathrm{mol} / \mathrm{l})$ & 56 & 19 & 68 & 24 & \\
\hline Gly $(\mu \mathrm{mol} / \mathrm{l})$ & 286 & 42 & 281 & 38 & \\
\hline $\operatorname{Ser}(\mu \mathrm{mol} / 1)$ & 173 & 19 & 200 & 9 & \\
\hline $\mathrm{Tau}(\mu \mathrm{mol} / \mathrm{l})$ & 44 & 12 & 48 & 14 & \\
\hline Insulin (mU/1) & 61 & 21 & 121 & 52 & \\
\hline Glucagon (ng/1) & 312 & 107 & 453 & 178 & 0.008 \\
\hline Growth hormone $(\mu \mathrm{U} / 1)$ & 8.66 & 2.76 & 9.53 & 3.42 & \\
\hline IGF-I $(\mu \mathrm{g} / 1)$ & 35 & 8 & 45 & 13 & \\
\hline IGFBP-3 $(\mu \mathrm{g} / 1)$ & 857 & 292 & 1095 & 342 & \\
\hline Free $T_{3}(\mathrm{pmol} / \mathrm{l})$ & 4.66 & 0.64 & 5.94 & 0.97 & 0.018 \\
\hline Free $T_{4}(\mathrm{pmol} / 1)$ & $14 \cdot 8$ & 1.8 & 16.4 & $2 \cdot 3$ & \\
\hline $\mathrm{TSH}(\mathrm{mU} / \mathrm{l})$ & 1.59 & 0.37 & $1 \cdot 27$ & 0.20 & \\
\hline
\end{tabular}

IGF, insulin-like growth factor; IGFBP, insulin-like growth factor-binding protein; $T_{3}$, triiodothyronine; $T_{4}$, thyroxine; $\mathrm{TSH}$, thyroid-stimulating hormone.

*For details of patients and procedures, see Table 1 and pp. 198-200.

†Reference values cannot be given for this fed state condition. However, some hormones are believed not to fluctuate with diurnal dietary intake and $95 \%$ reference values for these hormones can be given tentatively. IGF-I 67-264 $\mu \mathrm{g} / \mathrm{l}, \mathrm{IGFBP}-31957-5065 \mu \mathrm{g} / 1$, free $\mathrm{T}_{3} 5.0-10.0 \mathrm{pmol} / 1$, free $\mathrm{T}_{4}$ 9.0-28.0 pmol/1, TSH 0.40-3.80 mU/1. 
Table 6 shows the effect of a standardized meal-test $(50 \mathrm{~kJ} / \mathrm{kg}$ and $0.4 \mathrm{~g}$ protein $/ \mathrm{kg})$ after an overnight fast in four patients in the 4-week protocol, at the beginning and at the end of the refeeding period. The results given for the 'meal' condition are means of the $1 \mathrm{~h}$ and $3 \mathrm{~h}$ post-meal measurements. At the first meal test, free fatty acids decreased significantly and insulin increased significantly. When repeated at the end of the refeeding period the response of all substrates and hormones were similar to that of the first test-meal, except that the increase in insulin did not reach statistical significance $(P=0.052)$ and the increase in total amino acids was statistically significant, but quantitatively similar. No significant changes were observed in fasting levels of substrates and hormones before the second meal test. The composition of plasma amino acids was only measured in three of the four patients included in the meal test study. After the first meal, plasma leucine increased by 83 (SE 12)\% $(P=0.02)$ and total BCAA increased by 60 (SE 11) \% $(P=0.03)$. The increases in other amino acids did not reach statistical significance. These changes were the same after the second meal.

In order to identify the disturbance in protein metabolism underlying the increased protein requirement, the thirteen patients who participated in the present study were divided into two groups (Table 7). The patients were divided according to whether or not their protein requirement for $\mathrm{N}$ balance was within the value recommended for healthy individuals on a mixed diet $(0.8 \mathrm{~g} / \mathrm{kg}$ per d). The mean requirement in the 'highrequirement' group was almost twice as high compared with the 'normal-requirement' group (Table 7). The utilization of protein (i.e. the slope of linear regression of $\mathrm{N}$ balance $v$. protein intake) was identical in the two subgroups. The other data in Table 7 are from the initial investigation of protein metabolism. Protein intake coincidently was similar in the two subgroups. Urinary N excretion recalculated to protein was higher in the "highrequirement' group. Protein synthesis was similar in the two groups. Protein degradation was higher in the 'high-requirement' group and although this difference was not

Table 6. The effect of a single standard meal on plasma substrate and hormone levels in four patients with liver cirrhosis before and after 4 weeks of refeeding*

(Mean values with their standard errors)

\begin{tabular}{|c|c|c|c|c|c|c|c|c|c|}
\hline & & \multicolumn{2}{|c|}{ Initial test } & \multirow{2}{*}{$\begin{array}{c}\text { Statistical } \\
\text { significance } \\
\text { of difference } \uparrow: P\end{array}$} & \multicolumn{2}{|c|}{ Final test } & \multirow{2}{*}{$\begin{array}{c}\text { Statistical } \\
\text { significance } \\
\text { of difference } t: P\end{array}$} & \multicolumn{2}{|c|}{ Reference values } \\
\hline & & Mean & SE & & Mean & SE & & Mean & SE \\
\hline \multirow[t]{2}{*}{ Glucose (mmol/l) } & Fasting & $5 \cdot 64$ & 0.39 & & 5.83 & 0.17 & & 4.74 & 0.11 \\
\hline & Meal & 8.49 & 1.52 & & 7.77 & 1.55 & & & \\
\hline \multirow[t]{2}{*}{ Lactate $(\mathrm{mmol} / \mathrm{l})$} & Fasting & 1.40 & 0.30 & & $1 \cdot 20$ & 0.10 & & - & - \\
\hline & Meal & 1.55 & 0.13 & & 1.36 & 0.06 & & & \\
\hline \multirow{3}{*}{$\begin{array}{l}\text { Free fatty acids } \\
(\mathrm{mmol} / \mathrm{l})\end{array}$} & Fasting & 0.65 & 0.09 & & 0.70 & 0.11 & & - & - \\
\hline & Meal & 0.14 & 0.03 & 0.032 & 0.16 & 0.0 & 0.014 & & \\
\hline & & & & & & 3 & & & \\
\hline \multirow{2}{*}{$\begin{array}{c}\beta \text {-hydroxybutyrate } \\
(\mu \mathrm{mol} / \mathrm{l})\end{array}$} & Fasting & 97 & 10 & & 93 & 11 & & - & - \\
\hline & Meal & 80 & 5 & & 79 & 4 & & & \\
\hline \multirow{2}{*}{$\begin{array}{l}\text { Total amino acids } \\
(\mathrm{mmol} / \mathrm{l})\end{array}$} & Fasting & 2.95 & 0.20 & & 3.45 & 0.31 & & 3.40 & 0.11 \\
\hline & Meal & 3.38 & 0.17 & & 3.78 & 0.36 & 0.036 & & \\
\hline \multirow{2}{*}{ Insulin (mU/1) } & Fasting & 10 & 4 & & 15 & 3 & & 8 & 1 \\
\hline & Meal & 51 & 9 & 0.021 & 52 & 12 & & & \\
\hline \multirow[t]{2}{*}{ Glucagon (ng/l) } & Fasting & 79 & 20 & & 99 & 30 & & 76 & 9 \\
\hline & Meal & 82 & 13 & & 99 & 18 & & & \\
\hline
\end{tabular}

*For details of patients and procedures, see Table 1 and pp. 198-200.

$\dagger$ The difference between mean meal and fasting values was analysed by paired $t$ test.

$\ddagger$ Fasting values for healthy individuals from this laboratory (Hamberg \& Vilstrup, 1994). 
Table 7. Protein metabolism of patients with liver cirrhosis who had low or high protein requirements*

(Mean values with their standard errors)

\begin{tabular}{|c|c|c|c|c|c|}
\hline \multirow[t]{2}{*}{$\begin{array}{l}\text { Requirement (g/kg per d)... } \\
n \ldots\end{array}$} & \multicolumn{2}{|c|}{$\begin{array}{c}<0.8 \\
5\end{array}$} & \multicolumn{2}{|c|}{$\begin{array}{c}>0.8 \\
8\end{array}$} & \multirow{2}{*}{$\begin{array}{l}\text { Statistical significance } \\
\text { of difference: } P\end{array}$} \\
\hline & Mean & SE & Mean & SE & \\
\hline Requirement ( $\mathrm{g} / \mathrm{kg}$ per $\mathrm{d}$ ) & 0.63 & 0.05 & $1 \cdot 12$ & 0.12 & \\
\hline Utilization $(\mathrm{g} / \mathrm{g})$ & 1.04 & 0.15 & 0.91 & 0.12 & \\
\hline Intake $(\mathrm{g} / \mathrm{kg}$ per $\mathrm{d})$ & 1.06 & 0.18 & $1 \cdot 12$ & 0.12 & \\
\hline Excretion $(\mathrm{g} / \mathrm{kg}$ per $\mathrm{d}) \dagger$ & 0.52 & 0.07 & 0.93 & 0.08 & 0.005 \\
\hline Flux $(\mathrm{g} / \mathrm{kg}$ per $\mathrm{d})$ & 3.24 & 0.36 & 3.71 & 0.41 & \\
\hline Synthesis (g/kg per d) & $2 \cdot 72$ & 0.33 & 2.77 & 0.38 & \\
\hline Degradation ( $g / k g$ per d) & $2 \cdot 19$ & 0.34 & 2.58 & 0.38 & \\
\hline Degradation:synthesis & 0.79 & 0.04 & 0.94 & 0.04 & 0.03 \\
\hline Plasma amino acids (mM) & $2 \cdot 82$ & 0.29 & 3.45 & 0.22 & \\
\hline
\end{tabular}

*For details of patients and procedures, see Table 1 and pp. 198-200.

†Calculated from urinary $\mathrm{N}$ excretion $\times 6.25$.

statistically significant, it was numerically similar to the difference in excretion, in accordance with equation 3 . When expressed relative to protein synthesis, protein degradation was significantly higher in the 'high-requirement' group. The 'highrequirement' group had a higher (but not significant) mean value of total amino acids $(P=0 \cdot 11)$.

\section{DISCUSSION}

According to Table 1 the patients were moderately malnourished and had a moderate degree of liver disease. All patients were ambulatory and ten patients had ascites. In these respects the patients were similar to those studied earlier (Nielsen et al. 1995). None of the patients developed encephalopathy during refeeding. Table 2 shows that oral protein (and energy) intake was doubled within the 2 -week protocol. The more rapid increase in dietary intake in the 2-week protocol did not decrease protein utilization.

Results obtained with the $\left[{ }^{15} \mathrm{~N}\right]$ glycine method have been found previously to be similar to those obtained with labelled leucine (Golden \& Waterlow, 1977; Pacy et al. 1994). However, if the experimental conditions affect intermediary metabolism of glycine by other routes than protein synthesis and degradation, results can be interpreted erratically (Golden \& Jackson, 1981). In patients with liver cirrhosis, plasma $\left[{ }^{15} \mathrm{~N}\right]$ glycine elimination rate and urinary ${ }^{15} \mathrm{~N}$ appearance did not differ between patients and healthy controls after an oral dose of $\left[{ }^{15} \mathrm{~N}\right] \mathrm{glycine}$ (Kohno et al. 1990). A number of physiological and pathological conditions (dietary amino acid composition, glucose infusion, fasting, refeeding, hypophysectomy, treatment with growth hormone or corticotropin) do not affect intermediary glycine- $\mathrm{N}$ metabolism substantially, as discussed recently (Nielsen $e t$ al. 1994). The initial values in the present study for flux and rates of synthesis and degradation were, within $20 \%$ identical to those reported in healthy individuals at a similar protein intake, investigated by the same isotope method (Jeevanandam et al. 1986). In addition, the ratio between flux calculated from urinary $\mathrm{NH}_{3}$ and urinary urea was 0.75 (SE 0.04 ) in our initial study (data not shown) which is very close to the value reported by Jeevanandam et al. (1986). These observations indicate that patients with cirrhosis do not 
pose specific problems with the $\left[{ }^{15} \mathrm{~N}\right]$ glycine method. After refeeding, the ratio between flux calculated from urinary $\mathrm{NH}_{3}$ and urinary urea was changed slightly but not significantly (0.84 (SE 0.03$)$ ), and flux calculated from $\mathrm{NH}_{3}$ or urea both increased significantly after refeeding (data not shown), indicating that refeeding did not perturb the system substantially.

Previously, protein metabolism has been investigated in patients with liver cirrhosis in the diurnal fasting-fed state transition, after a single meal. Milikan $e t$ al. (1985) found a decrease in protein degradation while protein synthesis was unaffected. Swart et al. (1988) reported a significant improvement in $\mathrm{N}$ balance but the increase in protein synthesis and the decrease in protein degradation failed to reach statistical significance. Tessari et al. (1994) found a decrease in protein degradation but protein synthesis was not measured. Only one previous study (Bonkovsky et al. 1991) dealt with the effect of prolonged (3 weeks, intravenous) refeeding, but they only studied protein metabolism in the fasting state and found no effect of refeeding on protein synthesis or degradation.

As discussed by Millward (1990), regulatory mechanisms involved in growth probably differ from regulatory mechanisms involved in the diurnal fasting-fed state transition. The same distinction could apply to repletion after weight loss $v$. the diurnal fasting-fed state transition. In healthy volunteers, Pacy et al. (1994) found that in the fasting-fed state transition, protein synthesis increased and protein degradation decreased, and this was associated with a large increase in plasma insulin. The 2-week adaptation to various protein intakes (from insufficient to excessive levels) showed that an increased daily protein intake also led to increased protein synthesis and decreased protein degradation, as measured in the fed state. However, this was not associated with changes in plasma levels of insulin (or free $\mathrm{T}_{3}$ or IGF-I) but with an increase in plasma leucine. Part of their data is reproduced in Table 4. To facilitate a comparison with the protein intake in our 2-week protocol (Table 3 ), we have reproduced their results after 2-weeks feeding of either 0.75 or $1.5 \mathrm{~g} / \mathrm{kg}$ per d.

Our results agree with those of Pacy et al. (1994) in that increased protein synthesis, rather than decreased protein degradation, accounted quantitatively for most of the increase in $\mathrm{N}$ retention. In addition, our meal test study also showed a large increase in insulin, while prolonged refeeding only led to non-significant increases in insulin but significant increases in plasma amino acids, especially leucine and other BCAA.

The increased plasma level of amino acids may contribute to regulation of protein metabolism, as indicated by experiments with human subjects, in which amino acid infusion increased protein synthesis. This occurred to the same extent whether or not plasma insulin was kept at a basal fasting level or at a high level (Tessari et al. 1987; Castellino et al. 1987). With respect to individual amino acids, a possible regulatory role for leucine was suggested by studies in isolated rat muscle (Fulks et al. 1975) and in rats in vivo (Garlick \& Grant, 1988). Alanine and proline were suggested to increase hepatic protein synthesis in rats in vivo (Perez-Sala et al. 1987). However, the mechanism whereby amino acids may regulate protein synthesis is uncertain. Experiments in fasted mice suggest that dietary protein enhances protein synthesis via stimulation of both initiation and elongation activity (Yoshizawa et al. 1995).

In contrast to the results of Pacy et al. (1994), we found an increase in $T_{3}$ from initial borderline low $\mathrm{T}_{3}$ levels (Table 5). This could be due to increased intake of both protein and energy in our patients who initially were in a state of chronic malnutrition, known to be associated with low $T_{3}$ levels. In the study of Pacy et al. (1994), energy intake was kept constant. An increase in $T_{3}$ may facilitate protein synthesis under some conditions, but a direct effect of $T_{3}$ administration on protein synthesis could not be shown during refeeding of starved rats (Millward et al. 1988). Growth hormone and IGF-I did not increase 
significantly in our study, suggesting that these hormones were not responsible for the increase in protein synthesis. It is, however, difficult to give a definite interpretation of these results since, for example diurnal fluctuation of growth hormone and several binding proteins for IGF-I other than IGFBP-3 may affect the biological activity of these hormones. The observation that the response to a single meal was unchanged after 4 weeks refeeding (Table 6) is compatible with the view that refeeding did not substantially alter the hormonal milieu of the patients. Our results suggest that repletion after weight loss, with respect to whole-body protein metabolism, is due primarily to increased protein synthesis and that this increase is associated primarily with elevated levels of plasma amino acids. This agrees with conclusions from the study of healthy individuals (Pacy et al. 1994).

Concurrent with the high protein utilization which is considered to be similar to that of underweight, otherwise healthy, subjects (Nielsen et al. 1995), patients with liver cirrhosis in general require an increased amount of protein to reach $\mathrm{N}$ balance. In the present study eight of thirteen patients had an increased requirement (Table 7). Taken together with the high utilization this means that in patients with a high protein requirement there is a parallel shift to the right of the $\mathrm{N}$ retention $v$. protein intake curve (Nielsen et al. 1995) and, at any given intake, $\mathrm{N}$ retention will be less than that of underweight, otherwise healthy, subjects. In the preceding study (Nielsen et al. 1995), faecal energy and $\mathrm{N}$ content was similar to that of healthy individuals and the same applied to faecal $\mathrm{N}$ excretion in the patients of the present study (data not shown). In the absence of malabsorption the decreased $\mathrm{N}$ retention must be due to increased $\mathrm{N}$ excretion associated with decreased protein synthesis and/or increased protein degradation. According to Table 7 the increased protein requirement, and increased $\mathrm{N}$ excretion, was associated with increased protein degradation, rather than decreased protein synthesis. The results in Table 7 further suggest that the primary disturbance is increased protein degradation, rather than increased $\mathrm{N}$ excretion, since a primarily increased $\mathrm{N}$ excretion, as induced by infusion of glucagon, decreases protein synthesis but it does not increase protein degradation (Pacy et al. 1990). In addition, glucagon infusion decreases plasma amino acid levels (Couet et al. 1990) but the 'high-requirement' group in Table 7 tended to have an elevated total plasma amino acid concentration, consistent with the hypothesis that increased degradation is the primary disturbance.

Increased protein degradation has previously been reported after a single meal in patients with liver cirrhosis, compared with healthy control subjects (Swart et al. 1988; Tessari et al. 1994). However, these studies failed to explain the increased protein requirement. In the first study (Swart et al. 1988), protein synthesis was also increased and $\mathrm{N}$ balance was more positive in the patients as compared with normal-weight healthy controls, as would be expected when feeding underweight individuals. In the other study (Tessari et al. 1994), $\mathrm{N}$ balance was not measured and the metabolic fate of amino acids produced by protein degradation (i.e. protein synthesis $v . \mathrm{N}$ excretion) was not investigated. Protein degradation, also, has been found to be increased after an overnight fast, but not in all studies (McCullough \& Glamour, 1993). In the present study, protein degradation was observed to be increased during feeding in patients who had an increased protein requirement, as estimated from subsequent $24 \mathrm{~h}$ balance periods of several weeks duration. This indicates that the mechanism underlying the increased protein degradation, and increased protein requirement, is not confined to the nocturnal fasting period, as suggested by Swart et al. (1988).

It was shown previously that there is no correlation between protein requirement and resting energy expenditure (Nielsen et al. 1995). One possible explanation for the increased rate of protein degradation could be the low plasma levels of IGF-I (Table 5), since IGF-I is 
known to inhibit protein degradation (Elahi et al. 1993; Giordana et al. 1995) and to improve $\mathrm{N}$ balance in individuals with low IGF-I levels, such as semi-starved healthy individuals (Clemmons et al. 1992) and normal-weight elderly women given a weightmaintaining diet (Thompson et al. 1995). In the present study, initial plasma concentrations of IGF-I and IGFBP-3 were 22 and $24 \%$ respectively of age- and sex-matched mean values (Juul et al. 1995 and unpublished results relating to data for 316 healthy individuals at age 50 years). The persistence of low levels in our patients during refeeding indicates that the low levels are due to impaired liver function since plasma IGF-I is normalized within $8 \mathrm{~d}$ of refeeding healthy individuals (Clemmons \& Underwood, 1991). The lack of increase in IGF-I during refeeding could require a compensatory higher protein intake, before the balance between protein synthesis and degradation converts to net anabolism.

With the aim of identifying a clinical correlate to the increased protein requirement, we subdivided all twenty patients in whom protein requirement had been estimated in the present and the preceding studies (Nielsen et al. 1995). Patients with an increased protein requirement (i.e. $>0.8 \mathrm{~g} / \mathrm{kg}$ per d; $n 11$ (of the twenty patients)) tended to have higher levels of plasma bilirubin and alanine aminotransferase ( $E C$ 2.6.1.2), a decreased galactose elimination capacity and a more severe degree of liver disease (higher Child-Pugh score (Pugh et al. 1973)), but none of these differences were significantly different. Further, nutritional status (LBM from three $\times 24 \mathrm{~h}$ creatinine excretions, mid-arm-muscle area or triceps skinfold), amount and duration of alcohol intake, or time lapse from admission to starting the refeeding protocol, or any other variable included in Table 1, did not differ between the two groups (data not shown). Linear regression analysis and multiple regression analysis were also unable to identify clinical correlates to the increased protein requirement. More specifically, it was considered that protein wasting in the form of myopathy is common in chronic alcoholics, also in those without liver disease (Martin $e t$ al. 1985; Preedy et al. 1994), and that lack of alcohol abstinence in patients with cirrhosis is associated with increased protein turnover, compared with abstinent individuals (Hirsch et al. 1995). However, according to our analysis, neither alcohol intake, duration of alcohol abuse or duration of abstinence before refeeding were related to increased protein requirement.

In summary, the present and the preceding studies (Nielsen et al. 1993, 1995) have shown, by application of the ' $\mathrm{N}$ retention $v$. $\mathrm{N}$ intake' methodology, that increased requirement, rather than decreased utilization, is the abnormality of $\mathrm{N}$ retention in patients with liver cirrhosis. Furthermore, our results suggest that these two components of the retention $v$. intake curve are distinct entities since utilization was the same in the two subgroups divided according to protein requirement (Table 7). It also appears, at least in our patients, that the two components are controlled in distinctly separate ways: utilization by protein synthesis and requirement by protein degradation.

Even when clinically stable, the spontaneous intake of these patients is very close to the requirement for balance (Nielsen et al. 1993) and, therefore, they are prone to rapid protein wasting in periods with decreased appetite (due to ascites, infection, bleeding etc.). In the absence of clinical correlates that can identify patients with an increased protein requirement, we suggest (from the data in Table 7) that these patients are identified by measurement of urinary $\mathrm{N}$ excretion at an intake of $1 \mathrm{~g}$ protein $/ \mathrm{kg}$ per $\mathrm{d}$. Patients in positive balance at this intake can be considered not to have an increased requirement. Other patients require larger amounts of protein to achieve $\mathrm{N}$ balance. A therapeutic approach with partial substitution of ordinary protein with BCAA failed to reduce the protein requirement for $\mathrm{N}$ balance (Swart et al. 1989), compatible with the view that BCAA may be especially important for protein utilization which is already highly efficient. 
Instead, dietary substances or hormonal factors (such as IGF-I) that can reduce protein degradation specifically may be useful in these patients.

The Danish Medical Research Council (grant no. 12-9539), the P. Carl Petersen Foundation, Jeppe Juhl's Memorial Fund, The Danish Foundation for Advancement of Medical Science and NOVO Research Foundation are acknowledged for financial support. The skilful technical assistance of Lise Lotte Hansen is gratefully acknowledged. Dr Niels Grunnet, Department of Biochemistry A, The Panum Institute, Copenhagen, Denmark, is acknowledged for measurement of plasma amino acids. NOVO Nordisk Ltd, Copenhagen, Denmark is acknowledged for a generous supply of kits for determination of insulin and glucagon.

\section{REFERENCES}

Bang, P., Eriksson, U., Sara, V., Wivall, I.-L. \& Hall, K. (1991). Comparison of acid ethanol extraction and acid gel filtration prior to IGF-I and IGF-II radioimmunoassays: Improvement of determinations in acid ethanol extracts by the use of truncated IGF-I as radioligand. Acta Endocrinologica 124, 620-629.

Bingham, S. \& Cummings, J. H. (1983). The use of 4-aminobenzoic acid as a marker to validate the completeness of $24 \mathrm{~h}$ urine collection in man. Clinical Science 64, 629-635.

Bingham, S. \& Cummings, J.H. (1985). Urine nitrogen as an independent validatory measure of dietary intake: a study of nitrogen balance in individuals consuming their normal diet. American Journal of Clinical Nutrition 42, 1276-1289.

Blum, W. F., Ranke, M. B., Kietzmann, K., Gauggel, E., Zeisel, H. J. \& Bierich, J. R. (1990). A specific radioimmunoassay for the growth hormone $(\mathrm{GH})$-dependent somatomedin-binding protein: its use for diagnosis of GH deficiency. Journal of Clinical Endocrinology and Metabolism 70, 1292-1298.

Bonkovsky, H. L., Singh, R. H., Jafri, I. H., Fiellin, D. A., Smith, G. S., Simon, D., Cotsonis, G. A. \& Slaker, D. P. (1991). A randomized, controlled trial of treatment of alcoholic hepatitis with parenteral nutrition and oxandrolone. II. Short-term effects on nitrogen metabolism, metabolic balance, and nutrition. American Journal of Gastroenterology 86, 1209-1218.

Castellino, P., Luzi, L., Simonsen, D. C., Haymond, M \& DeFronzo, R. A. (1987). Effect of insulin and plasma amino acid concentrations on leucine metabolism in man. Journal of Clinical Investigation 80, 1784-1793.

Clemmons, D. R., Smith-Banks, A. \& Underwood, L. E. (1992). Reversal of diet-induced catabolism by infusion of recombinant insulin-like growth factor-I in humans. Journal of Clinical Endocrinology and Metabolism 75, 234-238.

Clemmons, D. R. \& Underwood, L. E. (1991). Nutritional regulation of IGF-I and IGF binding protein. Annual Reviews of Nutrition 11, 393-412.

Couet, C., Fukagawa, N. K., Matthews, D. E., Bier, D. M. \& Young, V. R. (1990). Plasma amino acid kinetics during acute states of glucagon deficiency and excess in healthy adults. American Journal of Physiology 258, E78-E85.

Elahi, D., McAloon-Dyke, M., Fukagawa, N. K., Sclater, A. L., Wong, G. A., Shannon, R. P., Minaker, K. L., Miles, J. M., Rubenstein, A. H., Vandepol, C. J., Guler, H.-P., Good, W. R., Swaman, J. J. \& Wolfe, R. R. (1993). Effect of recombinant human IGF-I on glucose and leucine kinetics in men. American Journal of Physiology 265, E831-E838.

Fern, E. B., Garlick, P. J. \& Waterlow, J. C. (1985). The concept of the single body pool of metabolic nitrogen in determining the rate of whole-body nitrogen turnover. Human Nutrition: Clinical Nutrition 39C, 85-99.

Fulks, R. M., Li, J. B. \& Goldberg, A. L. (1975). Effects of insulin, glucose, and amino acids on protein turnover in rat diaphragm. Journal of Biological Chemistry 250, 290-298.

Garlick, P. J. \& Grant, I. (1988). Amino acid infusion increase the sensitivity of muscle protein synthesis in vivo to insulin. Journal of Biochemistry 254, 579-584.

Giordana, M., Castellino, P., Carroll, C. A. \& DeFronzo, R. A. (1995). Comparison of the effects of human recombinant insulin-like growth factor I and insulin on plasma amino acid concentrations and leucine kinetics in humans, Diabetologia 38, 732-738.

Golden, M. H. N. \& Jackson, A. A. (1981). Assumptions and errors in the use of ${ }^{15} \mathrm{~N}$-excretion data to estimate whole body protein turnover. In Nitrogen Metabolism in Man pp. 323-343 [J. C. Waterlow and J. M. L. Stephen, editors]. London: Applied Science Publisher.

Golden, M. H. N. \& Waterlow, J. C. (1977). Total protein synthesis in elderly people: a comparison of results with ${ }^{15} \mathrm{~N}$ glycine and ${ }^{14} \mathrm{C}$ leucine. Clinical Science and Molecular Medicine 53, 277-288.

Goodwin, J. F. (1970). Spectrophotometric quantitation of plasma and urinary amino nitrogen with fluorodinitrobenzene. Standard Methods of Clinical Chemistry 6, 89-98. 
Hamberg, O. \& Vilstrup, H. (1994). Effects of glucose on hepatic conversion of amino-nitrogen to urea in patients with cirrhosis: Relationship to glucagon. Hepatology 19, 45-54.

Hirsch, S., Maza, P. M., Petermann, M., Iturriaga, H., Ugarte, G. \& Bunout, D. (1995). Protein turnover in abstinent and non-abstinent patients with alcoholic cirrhosis. Journal of the American College of Nutrition 14, 99-104.

Jeevanandam, M., Lowry, S. F., Horowitz, G. D., Legaspi, A. \& Brennan, M. F. (1986). Influence of increasing dietary intake on whole body protein kinetics in normal man. Clinical Nutrition 5, 41-48.

Juul, A., Dalgaard, P., Blum, W. F., Bang, P., Hall, K., Michaelsen, K. F., Müller, J. \& Skakkebaek, N. E. (1995). Serum levels of insulin-like growth factor (IGF)-binding protein-3 (IGFBP-3) in healthy infants, children and adolescents: The relation to IGF-I, IGF-II, IGFBP-1, IGFBP-2, age, sex, body mass index, and pubertal maturation. Journal of Clinical Endocrinology and Metabolism 80, 2534-2542.

Kohno, M., Fujii, T. \& Hirayama, C. (1990). ${ }^{15} \mathrm{~N}$ Glycine metabolism in normal and cirrhotic subjects. Biochemical Medicine and Metabolic Biology 43, 201-213.

Kondrup, J., Nielsen, K. \& Hamberg, O. (1992). Nutritional therapy in patients with liver cirrhosis. European Journal of Clinical Nutrition 46, 239-246.

Lautz, H. U., Selberg, O., Küber, J., Bürger, M. \& Müller, M. J. (1992). Forms of malnutrition in patients with liver cirrhosis. Clinical Investigator 70, 478-486.

McCullough, A. \& Glamour, T. (1993). Differences in amino acid kinetics in cirrhosis. Gastroenterology 104, 1858-1864.

Martin, M., Ward, K., Slavin, G., Levi, J. \& Peters, T. J. (1985). Alcoholic skeletal myopathy, a clinical and pathological study. Quarterly Journal of Medicine 55, 233-251.

Milikan, W. J., Henderson, J. M., Galloway, J. R., Warren, W. D., Matthews, D. E., McGhee, A. \& Kutner, M. H. (1985). In vivo measurement of leucine metabolism with stable isotopes in normal subjects and in those with cirrhosis fed conventional and branched-chain amino acid-enriched diets. Surgery 98, 405-413.

Millward, D. J. (1990). The hormonal control of protein tumover. Clinical Nutrition 9, 115-126.

Millward, D. J., Brown, J. G. \& van Bueren, J. (1988). The influence of plasma concentrations of triiodothyronine on the acute increases in insulin and muscle protein synthesis in the refed fasted rat. Journal of Endocrinology 118, 417-422.

Nielsen, K, Kondrup, J., Elsener, P., Juul, A. \& Jensen, E. S. (1994). Casein and soya-bean protein have different effects on whole-body protein turnover at the same nitrogen balance. British Journal of Nutrition 72 , 69-81.

Nielsen, K., Kondrup, J., Martinsen, L., Døssing, H., Larsson, B., Stilling, B. \& Jensen, M. G. (1995). Long-term oral refeeding of patients with cirrhosis of the liver. British Journal of Nutrition 74, 557-567.

Nielsen, K., Kondrup, J., Martinsen, L., Stilling, B. \& Wikman, B. (1993). Nutritional assessment and adequacy of dietary intake in hospitalized patients with alcoholic liver cirrhosis. British Journal of Nutrition 69, 665679.

Pacy, P. J., Cheng, K. N., Ford, G. C. \& Halliday, D. (1990). Influence of glucagon on protein and leucine metabolism: a study in fasting man with induced insulin resistance. British Journal of Surgery 77, 791-794.

Pacy, P. J., Price, G. M., Halliday, D., Quevedo, M.-R. \& Millward, D. J. (1994). Nitrogen homeostasis in man: the diumal responses of protein synthesis and degradation and amino acid oxidation to diets with increasing protein intakes. Clinical Science 86, 103-118.

Perez-Sala, D., Parrilla, R. \& Ayuso, M. S. (1987). Key role of L-alanine in the control of hepatic protein synthesis. Biochemical Journal 241, 491-498.

Picou, D. \& Taylor-Roberts, T. (1969). Measurement of total protein synthesis and catabolism and nitrogen turnover in infants in different nutritional states and receiving different amounts of dietary protein. Clinical Science 36, 283-296.

Preedy, V. R., Peters, T. J., Patel, V. B. \& Miell, J. P. (1994). Chronic alcoholic myopathy: transcription and translational alterations. FASEB Journal 8, 1146-1151.

Pugh, R. N. H., Murray-Lyon, I. M., Dawson, J. L., Pietroni, M. C. \& Williams, R. (1973). Transection of the oesophagus for bleeding oesophageal varices. British Joumal of Surgery 60, 646-649.

Swart, G. R., van den Berg, J. W. O., van Vuure, J. K., Tietveld, T., Wattimena, D. L. \& Frenkel, M. (1989). Minimum protein requirements in liver cirrhosis determined by nitrogen balance measurements at three levels of protein intake. Clinical Nutrition 8, 329-336.

Swart, G. R., van den Berg, J. W. O., Wattimena, J. L. D., Rietveld, T., Van Vuure, J. K. \& Frenkel, M. (1988). Elevated protein requirement in cirrhosis of the liver investigated by whole body protein turnover studies. Clinical Science 75, 101-107.

Tessari, P., Inchiostro, S., Biolo, G., Trevisan, R., Fantin, G., Marescotti, M. C., Iori, E., Tiengo, A. \& Crepaldi, C. (1987). Differential effects of hyperinsulinemia and hyperaminoacidemia on leucine-carbon metabolism in vivo. Journal of Clinical Investigation 79, 1062-1069.

Tessari, P., Inchiostro, S., Barazzoni, R., Zanetti, M., Orlando,R., Biolo, G., Sergi, G., Pino, A. \& Tiengo, A. (1994). Fasting and postprandial phenylalanine and leucine kinetics in liver cirrhosis. American Journal of Physiology 267, E140-E149. 
Thompson, J. L., Butterfield, G. E., Marcus, R., Hintz, R. L., van Loan, M., Ghiron, L. \& Hoffman, A. R. (1995). The effects of recombinant human insulin-like growth factor-I and growth hormone on body composition in elderly women. Journal of Clinical Endocrinology and Metabolism 80, 1845-1852.

Tygstrup, N. (1966). Determination of the hepatic elimination capacity (Lm) of galactose by single injection. Scandinavian Journal of Clinical and Laboratory Investigation 18, 118-125.

Yoshizawa, F., Endo, M., Ide, H., Yagasaki, K. \& Funabiki, R. (1995). Translational regulation of protein synthesis in the liver and skeletal muscle of mice in response to refeeding. Journal of Nutritional Biochemisty 6, 130-136. 